\title{
Exploiting human memory B cell heterogeneity for improved vaccine efficacy
}

\section{Noel T. Pauli ${ }^{1,2}$, Carole J. Henry Dunand ${ }^{2}$ and Patrick C. Wilson ${ }^{1,2 *}$}

${ }^{1}$ Committee on Immunology, Section of Rheumatology, The Knapp Center for Lupus and Immunology Research, The University of Chicago, Chicago, IL, USA

${ }^{2}$ The Department of Medicine, Section of Rheumatology, The Knapp Center for Lupus and Immunology Research, The University of Chicago, Chicago, IL, USA

\section{Edited by:}

Katja Fink, Singapore Immunology Network, Agency for Science,

Technology and Research A*Star, Singapore

Reviewed by:

Raul M. Torres, University of Colorado Denver and National Jewish Health,

USA

Thomas Winkler, University

Erlangen-Nürnberg, Germany

*Correspondence:

Patrick C. Wilson, Department of Medicine/Rheumatology, Knapp

Center for Lupus and Immunology

Research, Committee on

Immunology, The University of

Chicago, BSLC/Jules F. Knapp

Building, 924 East 57th Street, R414,

Chicago, IL 60637, USA.

e-mail:wilsonp@uchicago.edu
The major goal in vaccination is establishment of long-term, prophylactic humoral memory to a pathogen. Two major components to long-lived humoral memory are plasma cells for the production of specific immunoglobulin and memory B cells that survey for their specific antigen in the periphery for later affinity maturation, proliferation, and differentiation. The study of human B cell memory has been aided by the discovery of a general marker for B cell memory, expression of CD27; however, new data suggests the existence of $\mathrm{CD} 27^{-}$memory $\mathrm{B}$ cells as well. These recently described non-canonical memory populations have increasingly pointed to the heterogeneity of the memory compartment. The novel B memory subsets in humans appear to have unique origins, localization, and functions compared to what was considered to be a "classical" memory B cell. In this article, we review the known B cell memory subsets, the establishment of B cell memory in vaccination and infection, and how understanding these newly described subsets can inform vaccine design and disease treatment.

Keywords: B cell, memory B cell, antibody, vaccine, B cell subset, influenza, anthrax, immunoglobulin

\section{INTRODUCTION}

\section{THE DISCOVERY OF IMMUNOLOGICAL MEMORY}

Immunological memory as a biological phenomenon has its roots in a simple, but powerful, observation; exemplified by Thucydides during an outbreak of the plague in Athens during the summer of $430 \mathrm{BC}$, "Yet it was with those who had recovered from the disease that the sick and the dying found most compassion. These knew what it was from experience, and had now no fear for themselves; for the same man was never attacked twice - never at least fatally" (Thucydides et al., 1996). This observation was utilized in the vaccination experiments much later by Edward Jenner and Louis Pasteur. Jenner being the first to realize in Western society that people could be protected against the disease smallpox by immunizing the individual first with the avirulent cowpox; the term "vaccine" derives its name from the Vaccinia virus of smallpox (Morgan and Parker, 2007). Pasteur took these observations a step further during his famous cholera experiments in chickens; where he discovered that components of the pathogen, derived in a laboratory setting, could be used to create a protective immune response (Pasteur, 1881a,b). Essentially, with the correct material, any disease had the potential to be vaccinated against without having to find an avirulent relative in nature (Pasteur, 1881a,b).

Pasteur and Jenner had stumbled upon one of the most advantageous traits of the vertebrate adaptive immune system, immunological memory, and through their studies they discovered how to purposefully unlock the phenomena. It was this principal that allowed vaccinology to flourish; dampening or outright eliminating major disease threats that have plagued our species throughout recorded history.

\section{GENERATION OF MEMORY}

The major goal of the adaptive immune system after every infection is to remember the insult and provide proper, effective protection upon secondary challenge by the same pathogen; in doing so, usually preventing the symptoms of the disease. Most vaccines are designed to protect against pathogens by generating humoral immune responses, which prevent the entry and establishment of an infection (Ahmed et al., 2007). In order to create useful memory to an immunological insult the body requires both $\mathrm{T}$ and $\mathrm{B}$ cells; the primary focus of this review will be the $\mathrm{B}$ cell compartment.

Humoral immunity is initiated from naïve $B$ cells in the peripheral blood that enter lymph nodes through the lymphatic system. Upon entering the lymph node, these B cells have the ability to sample antigen presented on subcapsular macrophages in the form of immune complexes and later interact with networks of follicular dendritic cells (FDCs) during a germinal center (GC) reaction (Szakal et al., 1988; Junt et al., 2007; Phan et al., 2009). If a B cell is able to bind antigen through its $B$ cell receptor (BCR), it will internalize the complex and present the processed antigen on major histo-compatibility complex class II (MHC class II) molecules to $\mathrm{CD}^{+}{ }^{+} \mathrm{T}$ cells at the T-B boarder (Lanzavecchia, 1990; Van Kooten and Banchereau, 2000, \#3189; Okada et al., 2005). Later on in the response this help will be provided by a subpopulation of $\mathrm{T}$ cells that localize to GCs known as T Follicular Helper cells ( $\mathrm{T}_{\mathrm{FH}}$ cells; Lanzavecchia, 1990; Van Kooten and Banchereau, 2000; Haynes 
et al., 2007). The B cells will then be informed that they bind to an immunologically relevant antigen through T cell receptor (TCR)MHC class II and CD40-CD40L interactions (Banchereau and Rousset, 1991; Jaiswal and Croft, 1997). This interaction informs the B cell to enter a GC reaction (Liu et al., 1991b). In such a state $\mathrm{B}$ cells begin to rapidly divide as centroblasts in the dark zone of the GC (Liu et al., 1991b). The activation of one of these cells by this cognate ligand allows for a massive proliferative response first postulated by Burnet (1957) and Talmage (1957) in their theory of clonal selection. As they divide, the cells mutate their Immunoglobulin (Ig) genes through the process known as somatic hypermutation (SHM; Weigert et al., 1970). SHM is controlled through the expression of the enzyme activation-induced cytidine deaminase (AID; Muramatsu et al., 2000; Revy et al., 2000). This enzyme also allows for class-switch recombination (CSR), which is the exchange of the heavy chain constant (C) regions of antibodies to different $\mathrm{C}$ regions down the Ig locus (Kincade et al., 1970). The isotype that is produced in the $\mathrm{B}$ cell will depend greatly on the cytokine milieu experienced by the B cell (Snapper and Paul, 1987). CSR will alter the effector function of the antibody but not its specificity. After rounds of rapid division and mutation, B cells emerge from the GC to test their altered BCR's specificity against the antigen presented on FDCs (Nieuwenhuis and Opstelten, 1984; Victora et al., 2010). Again they attempt to acquire T cell help, occurring in the light zone of the GC as centrocytes; if the B cell was successful in acquiring antigen, it will again be able to obtain T cell help through MHC class II-TCR interactions (Victora et al., 2010). If this interaction is unsuccessful, the B cell will die by apoptosis (Liu et al., 1989). However, if the B cell is able to get help, it will upregulate the survival markers, such as $\mathrm{Bcl} 2$, and graduate that round of GC selection; allowing it to again enter for another round (Liu et al., 1991a). This process is known as affinity maturation. Eventually, antigen will become limiting as the immune response wanes; leading to only the highest affinity BCRs being able to compete for antigen and acquire the crucial T cell help (Schwickert et al., 2011). These cells can exit the GC reaction as either antibody secreting cells (ASCs), such as plasmablasts and long-lived plasma cells, or they can leave as memory $B$ cells, which then take up residence in tissue and circulate in the peripheral blood to survey for their antigen (Arpin et al., 1995).

Memory B cells can be stimulated later on by means of specific interaction with their antigen or by polyclonal stimulation; resulting in the creation of plasmablasts and plasma cells that can produce a high affinity, specific antigen response (Bernasconi et al., 2002). This idea however, has been challenged by human findings that have shown no serum level changes in antibodies to a panel of vaccinating antigens when individuals are stimulated with boosters or experience infection reactivation with exception to the response to the recent antigen of challenge (Amanna et al., 2007, \#5460). Importantly, these cells are able to respond to their antigen of interest faster than naïve $B$ cells by not requiring cognate T cell help for activation through the receptor-intrinsic costimulation created following class-switch (Klinman and Doughty, 1973; Liu et al., 1995; Hebeis et al., 2004; Engels et al., 2009). Interestingly, there appears to be an intricate orchestration of the memory response; most recently demonstrated in mouse models. GC reactions can produce both long-lived, somatically mutated IgM, and isotype-switched memory B cells (Dogan et al., 2009; Pape et al., 2011). Somatically mutated $\operatorname{IgM}^{+} \mathrm{B}$ cells appear to be the predominate population in the revival of GCs during secondary responses, while isotype-switched memory B cells engaged in effector functions against the insult; promoting the idea that each isotype may have a specific role during a memory response to pathogen (Dogan et al., 2009; Pape et al., 2011). Collectively, these properties of the memory B cell compartment allow for a more potent response following secondary exposure to the cognate antigen.

For the purposes of this review, we will define memory B cells as B cells that are long-lived, antigen experienced, transferrable to non-immune host, and quiescent cells that require reactivation. This last criterion helps to distinguish these cells from terminally differentiated plasma cells that are always active and producing Ig. While the definition of what constitutes a memory cell is relatively simple to derive in theory; actually characterizing a population of cells that are bona-fide memory cells by this definition has taken significant effort and will be the primary focus of this review. The generation of memory responses is critical for the effective response to a vaccine and invading pathogens. These responses do not produce a homogenous population of memory cells but a constellation of subsets depending on the kinetic time point, location, and type of infection or vaccination. It has been in these contexts that a large number of memory cell subsets have been observed. Understanding these subsets will be paramount in the creation of novel, effective vaccines to pathogens that do not lend themselves easily to vaccination. In this review, we discuss the distinct subsets of $\mathrm{B}$ cells that comprise the larger population of "memory B cells" in humans. It is hoped that by better understanding these memory $B$ cell subsets, treatments can be devised to take advantage or avoid the formation of these varied compartments.

\section{THE DISCOVERY OF CD27}

Before the advent of CD27 as a general marker for human memory B cells, expression of several different markers was relied upon to parse out memory populations. Expression of the immunoglobulin isotype $\operatorname{IgD}$ was typically used as a means of removing naïve B cells populations; as was the marker CD38 to distinguish GC B cells (Liu et al., 1989; Pascual et al., 1994). To survey positively for memory cells, expression of IgG and IgA could be assayed as evidence of antigen experience and isotype switch (Moller and Wigzell, 1965; Bourgois et al., 1977). This roundabout method for identifying memory cells would make comparative analysis of memory populations more difficult; which has been a major pitfall in mouse models for many years, due to the lack of a unifying memory B cell marker.

Maurer et al. (1990) discovered a population of B cells expressing a previously known T cell marker, CD27 (Black et al., 1978; Eisenbarth et al., 1980). Importantly, the population of $\mathrm{CD} 27^{+} \mathrm{B}$ cells discovered were in high prevalence in adult peripheral blood but not present in fetal cord blood (Maurer et al., 1990). These $\mathrm{CD}^{+} 7^{+} \mathrm{B}$ cells also expressed $\operatorname{IgM}$ and $\operatorname{IgD}$ at significantly lower frequencies than $\mathrm{CD}^{-} 7^{-}$B cells as well as secreted IgG and IgM in higher titer following stimulation, leading the authors to speculate that these cells were "pre-activated" (Maurer et al., 1990, 1992). CD27 is a TNF family member receptor whose ligand, 
CD70 or CD27L, is expressed on activated T and B cells (Bowman et al., 1994). Importantly, CD27-CD70 interaction has been seen to induce ASC development and antibody secretion (Agematsu et al., 1995, 1997, 1998a). Further analysis of the B cell populations expressing CD27 revealed a unique morphology, containing a larger amount of cytoplasm than $\mathrm{CD} 27^{-}$populations; lending further evidence that these cells were previously activated lymphocytes (Agematsu et al., 1997). Finally, in 1998, two back-to-back publications showed that these $\mathrm{CD} 27^{+}$cells were antigenically experienced in contrast with their $\mathrm{CD}_{2} 7^{-}$counterparts due to the increased load of somatic mutations in the variable genes of the $\mathrm{CD} 27^{+}$compartment of B cells; this effect being seen in both the peripheral blood and the splenic tissue, but absent in CD27- fraction of lymphocytes (Klein et al., 1998b; Tangye et al., 1998). This discovery, combined with previous findings, gave weight to the claim that this marker was a characteristic shared by all memory B cells. Notably, although not often used, the Tangye et al. (1998) report also found that memory cells express CD148. Interestingly, CD27 expression is not exclusive to memory B cells as ASCs also have high CD27 expression on their surface, these two populations can easily be differentiated through the presence of other markers such as CD38 and CD20 (Brokstad et al., 1995; Bernasconi et al., 2002; Wrammert et al., 2008a; Smith et al., 2009).

By defining a general marker for memory B cells in humans, more in-depth analysis of the phenotypes of memory populations has been made possible. However, as will be described later, CD27 has been more recently realized to be unable to fully characterize all memory B cell subsets, as several new populations have been discovered that have fallen outside the detection of this broad marker.

\section{DIFFERENT SUBSETS}

Since the definition of memory B cells in humans by CD27 expression, the capacity to discriminate B memory subsets has increased exponentially. Outside the discovery of a heterogeneous population of B cell memory subsets, questions remain concerning the generation and the function of many. We begin by describing the currently known subsets of human memory B cells. See Box 1.

\section{CD27 $^{+}$SWITCHED MEMORY CELLS $\left(\lg \mathrm{G}^{+} / \lg \mathrm{A}^{+} / \operatorname{lgE}^{+}\right)$}

Memory $\mathrm{B}$ cells in human have been originally described as $\mathrm{IgD}^{-} \mathrm{CD} 27^{+}$cells, which have undergone the CSR and SHM process, in comparison to $\operatorname{IgM}^{+} \operatorname{IgD}^{+} \mathrm{CD} 27^{-}$naïve $\mathrm{B}$ cells. These "classical" memory cells express IgG, IgA, or IgE and they derive from $\mathrm{T}$ cell-dependent (TD) response in the GC (Pascual et al., 1994). As discussed below, $\operatorname{IgM}^{+} \mathrm{CD} 27^{+}$cells are also memory subsets, but may have roles differing from the class-switched populations. The general function of these cells is to induce a rapid and robust response after re-exposure to a pathogen or antigen by the differentiation to high affinity plasma cells (Arpin et al., 1995). These cells recirculate in the peripheral blood, spleen, and tissues to survey for their cognate antigen (Klein et al., 1998b; Tangye et al., 1998; Montoya et al., 1999). It is interesting to consider that the various secondary, class-switched isotypes of Ig may represent a population multiplier. Clearly, the various isotypes utilize different intracellular domains as BCRs and are associated with specific functional roles such that an IgA "mucosal memory" cell may be quite distinct functionally from IgG1 or IgG4 expressing memory cells.

\section{TISSUE-SPECIFIC AND “TISSUE-LIKE” MEMORY: CD27-FCRL4+ MEMORY CELLS}

The advent of CD27 as a general memory marker allowed great strides in the study of the memory compartments of human B cells. It came as a great surprise when B cell subsets that appeared to be newly discovered members of the memory compartment were located but lacked the expression of CD27.

\begin{tabular}{|c|c|c|c|c|c|c|c|}
\hline & \multicolumn{4}{|c|}{$\mathrm{CD}^{2} 7^{+}$memory cells } & \multicolumn{3}{|c|}{ CD27- $^{-}$memory cells } \\
\hline & \multirow{2}{*}{$\begin{array}{l}\text { Switched } \lg G^{+} / \\
\lg A^{+} / \lg E^{+}\end{array}$} & \multirow{2}{*}{$\begin{array}{l}\text { Switched } \\
\lg D^{+} \lg M^{-}\end{array}$} & \multicolumn{2}{|c|}{ IgM memory } & \multirow[t]{2}{*}{ FCRL4 $^{+}$} & \multirow[t]{2}{*}{$\operatorname{lgG}^{+}$} & \multirow[t]{2}{*}{$\lg A^{+}$} \\
\hline & & & IgM-only & $\lg M^{+} \lg D^{+}$ & & & \\
\hline Origin & Late GC & Late GC & Early GC & $\begin{array}{l}\text { Early GC } \\
\text { GC-independent }\end{array}$ & Not known & Early GC & $\begin{array}{l}\text { GC- } \\
\text { independent }\end{array}$ \\
\hline $\begin{array}{l}\text { Tissue } \\
\text { distribution }\end{array}$ & $\begin{array}{l}\text { Second } \\
\text { lymphoid, PB }\end{array}$ & $\begin{array}{l}\text { Mucosal tissue, } \\
\text { PB }\end{array}$ & $\begin{array}{l}\text { Second } \\
\text { lymphoid, PB }\end{array}$ & $\begin{array}{l}\text { Second lymphoid } \\
\text { (MZ of spleen), } \\
\text { PB }\end{array}$ & MALT & $\begin{array}{l}\text { Second } \\
\text { lymphoid, PB }\end{array}$ & PB, gut? \\
\hline \multirow[t]{2}{*}{ Function } & TD response & TD/TI response & TD response? & TI response & Not known & $\begin{array}{l}\text { TD } \\
\text { response? }\end{array}$ & TI response? \\
\hline & Tl response? & $\begin{array}{l}\text { Basophil } \\
\text { activation }\end{array}$ & & TD response? & & & \\
\hline $\begin{array}{l}\text { Transcription } \\
\text { factor }\end{array}$ & RUNX1 & Not known & Not known & Notch2? & RUNX2, SOX5 & RUNX1? & Not known \\
\hline $\begin{array}{l}\% \text { of PB B } \\
\text { cells }\end{array}$ & $11-17$ & $1-3$ & 5 & 15 & $\begin{array}{l}<0.2 \% \text { in } \mathrm{PB} \\
(9.5 \% \text { in } \\
\text { tonsil) }\end{array}$ & $1-4$ & 4 \\
\hline
\end{tabular}


In 2003, work was being done to characterize a new set of $B$ cell inhibitory receptor genes, known as the Ig superfamily receptor translocation associated genes (IRTA; Miller et al., 2002; Falini et al., 2003). The gene IRTA1, encoding the orphan receptor Fc-receptor-like-4 (FCRL4) molecule, was present on mucosally associated B cells and contained several immunoreceptor tyrosinebased inhibitory motifs (ITIMs); these were later shown to be potent negative regulators of BCR signaling (Miller et al., 2002; Ehrhardt et al., 2003; Falini et al., 2003). The inhibitory function of FCRL4 in B cells was seen to be mediated by the protein SHP-1 (Ehrhardt et al., 2003).

When this population was later located in the tonsillar tissue of humans, it was found that the cells did not express the memory marker CD27 (Ehrhardt et al., 2005). This B cell population was not seen in the blood, spleen, or bone marrow of human patients (Miller et al., 2002; Ehrhardt et al., 2005). However, these tissue localized B cells did have evidence of SHM, CSR to IgG and IgA, and lacked expression of GC markers (Ehrhardt et al., 2005). These cells also carried conventional markers of activation as well as higher CD20 expression (Ehrhardt et al., 2005). Interestingly, these $\mathrm{CD} 27^{-} \mathrm{FCRL}^{+} \mathrm{B}$ cells were larger than their CD27 ${ }^{+}$FCRL4 $^{-}$counterparts and could be stimulated to secrete Ig using T cell cytokines but not BCR stimulation (Ehrhardt et al., 2005). A gene array analysis of FCRL4 ${ }^{+}$versus FCRL4 ${ }^{-}$cells from tonsillar tissues has revealed that these cells differ in their transcriptome profiles. Expression of the transcription factors RUNX1 and RUNX2 appears to be a major difference between these populations (Ehrhardt et al., 2008). Moreover, the FCRL4 ${ }^{+}$memory $\mathrm{B}$ cells have a distinct expression patterns for receptors, signal transduction molecules, and transcription factors (Ehrhardt et al., 2008). The function of these cells is not defined but they may be important in the mucosal immune response. The discovery of a new subset of tissue-specific memory B cells that were not identifiable by CD27 staining spurred the notion that the B cell memory compartment was much more intricate than initially assumed.

Recent work done in the surveying of B cell responses to HIV has revealed a population of B cells in the peripheral blood that appeared to share a similar phenotype to tissue-specific $\mathrm{CD}^{-}$FCRL4 $^{+} \mathrm{B}$ cells described in tonsillar tissues (Ehrhardt et al., 2005; Moir et al., 2008). Interestingly, these HIV-infected viremic patients were seen to have this $\mathrm{CD} 27^{-} \mathrm{FCRL}^{+}$population present in their peripheral blood at a frequency of $19 \%$ of total B cells, which is in stark contrast to the $<4 \%$ of the same population in healthy individuals (Moir et al., 2008). This cell population, deemed "tissue-like memory B cells," expressed markers of past SHM, albeit at a lower frequency and diversity than normal $\mathrm{CD} 27^{+}$memory cells, and showed a reduced tendency to proliferate in response to cognate antigen (Moir et al., 2008). These tissue-like memory B cells also expressed not only FCRL4, but a number of other inhibitory receptors and chemokine receptors that would reduce the likelihood of B-T cell interaction (Moir et al., 2008). Further, these tissue-like memory B cells had reduced capability to produce ASCs but were the cell population most specific for the HIV gp120 protein (Moir et al., 2008). Specific siRNA knockdown of FCRL4 and other inhibitory receptors led to a rescue of Ig secretion and proliferation in these tissue-like memory B cells (Kardava et al., 2011). This phenotype resembled what had been seen in exhausted CD8 ${ }^{+} \mathrm{T}$ cells (Day et al., 2006), giving credence to the idea that this was an "exhausted" memory B cell population (Moir et al., 2008).

Since the identification of an exhausted population of B cells, similar phenotypes have been witnessed in other chronic diseases such as malaria and hepatitis-C (Weiss et al., 2009; Charles et al., 2011). It would appear that chronic infections have means to alter human B cell populations to their own benefit; overstimulation of B cells can be quite deleterious to the host and needs to be properly regulated. Vaccines that safely overcome this exhaustion phenotype may be necessary in order to develop proper immunity to these chronic, dangerous diseases.

\section{CD27 $^{+} \lg \mathrm{D}^{+} \lg \mathrm{M}^{-}$MEMORY CELLS}

Naïve B cells typically express both $\operatorname{IgM}$ and $\operatorname{IgD}$ isotypes on their surface, the differential production of these two antibody isotypes is controlled by alternative splicing of the immunoglobulin heavy chain RNA transcripts (Early et al., 1980; Moore et al., 1981; Kinashi et al., 1987). Interestingly, there is a population of antigen experienced human $\mathrm{CD}_{27}{ }^{+} \mathrm{IgD}^{+} \mathrm{IgM}^{-}$, "IgD only," memory $\mathrm{B}$ cells in the blood and $\mathrm{IgD}^{+} \mathrm{IgM}^{-}$plasma cell population that reside specifically in respiratory mucosal linings of humans (Liu et al., 1996; Arpin et al., 1998; Klein et al., 1998a).

These cells were initially discovered in 1989 during investigations of human myeloma patients (Yasui et al., 1989; White et al., 1990). These $\mathrm{IgD}^{+} \mathrm{IgM}^{-} \mathrm{CD} 27^{+}$memory B cells or "C $\delta$ class-switched" cells are the product of a class-switch event at the $\mathrm{C} \mu$ and cryptic $\mathrm{C} \delta$ switch recombination regions of the Ig heavy chain or, interestingly, by a separate non-classical homologous recombination event (Yasui et al., 1989; White et al., 1990). $\mathrm{IgD}^{+} \mathrm{IgM}^{-} \mathrm{B}$ cells carry some of the largest SHM burdens seen to date in their Ig genes; along with having a large skewing for use of lambda light chains (Arpin et al., 1998; Klein et al., 1998a; Zheng et al., 2004) as well as highly restricted VH gene repertoires (Wilson et al., 2000; Zheng et al., 2004; Koelsch et al., 2007; Seifert et al., 2009), with 50-60\% of the BCRs being encoded by one of only two heavy chains; VH3-30 or VH4-34. VH4-34 has long been associated with B cell autoimmunity (Pascual et al., 1991, 1992; Pugh-Bernard et al., 2001). This plus high levels of receptor editing for both the heavy and light chain loci, combined with higher auto- and poly-reactivity scoring in healthy individuals have implicated these cells in being uniquely selected during B cell development and immune responses (Wilson et al., 2000; Zheng et al., 2004; Koelsch et al., 2007). B1 and marginal zone cells in mice also express poly-reactive prone BCRs from a highly restricted BCR repertoire (Kearney, 2005), thus one can postulate that like these populations, $\mathrm{IgD}^{+} \mathrm{IgM}^{-} \mathrm{CD} 27^{+}$might serve more specialized innate-like or tissue-specific roles.

More recently work has been performed on possible effector functions of $\mathrm{IgD}^{+} \mathrm{IgM}^{-}$B cells that supports the possibility that these cells are to some degree functional analogs to B1 or $\mathrm{MZ}$ cells. Plasmablasts from human samples were seen to develop in the respiratory mucosa and produce $\operatorname{IgD}$ that was specific for pathogens of the respiratory tract (Chen et al., 2009). Interestingly, the $\operatorname{IgD}$ that was produced was seen to bind strongly to the Fc receptors on the surface of basophils (Chen et al., 2009). This crosslinking of IgD on the surface of basophils lead to the 
release of $\mathrm{B}$ cell-activating factors and antimicrobial compounds (Chen et al., 2009). The authors concluded that these $\operatorname{IgD}^{+} \operatorname{IgM}^{-}$ plasma cells and $\mathrm{IgD}^{+} \mathrm{IgM}^{-} \mathrm{CD} 27^{+}$memory cells appear to play an important role in respiratory mucosal defense via the activation of basophil populations; providing at least one possible function for this mysterious cell population in vivo (Chen et al., 2009).

\section{CD27 $^{-} \lg \mathrm{G}^{+}$AND CD27 $^{-} \lg \mathrm{A}^{+}$MEMORY CELLS}

Further heterogeneity in memory $B$ cell subsets has been reported with $\mathrm{CD}^{-} 7^{-} \mathrm{IgG}^{+} \mathrm{B}$ cells that exhibit classic attributes of memory cells, including SHM and expression of co-stimulatory molecules (Fecteau et al., 2006; Wei et al., 2007). CD27- $\mathrm{IgG}^{+}$ and $\mathrm{CD}_{27}{ }^{+} \mathrm{IgG}^{+}$memory $\mathrm{B}$ cells differed in the distribution of IgG subclasses, with a predominance of IgG2 expression in $\mathrm{CD}^{2} 7^{+} \mathrm{IgG}^{+}$, while $\mathrm{CD}^{2} 7^{-} \mathrm{IgG}^{+}$expressed preferentially IgG3 (Fecteau et al., 2006). In humans, IgG2 antibodies are mainly reactive to polysaccharides while IgG3 antibodies more often react with proteins; the unique isotype distributions between these two populations further suggests that $\mathrm{CD}_{27}^{-} \mathrm{IgG}^{+} \mathrm{B}$ cells could be distinct in their function (Fecteau et al., 2006). Moreover, analysis by Berkowska et al. (2011) has led to the conclusions that CD27 ${ }^{-} \mathrm{IgG}^{+}$ cells are derived from early GC reactions, like IgM-only memory cells described below, whereas $\mathrm{CD}_{2} 7^{+} \mathrm{IgG}^{+}$cells are derived from consecutive GC reactions based on the replication history, SHM, and CSR data of these two populations. Interestingly, these $\mathrm{CD}^{-} 7^{-} \mathrm{IgG}^{+}$cells are expanded in SLE patients compared with healthy controls (Wei et al., 2007). It is not yet known how these cells effect disease progression.

A minor population of memory cells have been described as $\mathrm{CD}_{27}{ }^{-} \mathrm{IgA}^{+}$. These cells have fewer mutations than $\mathrm{CD} 27^{+} \mathrm{IgA}^{+}$ cells and they may originate from local GC-independent responses in the gut, such as $\operatorname{IgA}^{+} \mathrm{B}$ cells from the lamina propria (Berkowska et al., 2011). The function of this population remains to be studied.

Both $\mathrm{CD}_{27}^{-} \mathrm{IgA}^{+}$and $\mathrm{CD} 27^{-} \mathrm{IgG}^{+}$populations are increased in patients with HIV chronic infection and an increased IgA production by $\mathrm{CD}^{2} 7^{-} \mathrm{IgA}^{+}$cells was observed upon CD40 and TLR9 stimulation in vitro (Cagigi et al., 2009). These CD27- isotypeswitched memory cells $\left(\mathrm{IgG}^{+}\right.$and $\mathrm{IgA}^{+}$) can be discriminated from $\mathrm{CD}^{2} 7^{-}$naïve cells by the absence of ATP-binding cassette B1 transporter (ABCB1) activity (Wirths and Lanzavecchia, 2005). Therefore, CD27 ${ }^{-}$memory cells, in opposition to $\mathrm{CD} 27^{+}$memory cells, are essentially disconnected from any further regulation through CD70, the ligand of CD27, supporting once more their distinct roles in immune responses (Fecteau et al., 2006).

The diversity of memory B cells may reflect the different origins and nature of the encounter antigens; leading to different possible functions of these memory B cells. The real contribution of each subset in the immune response should be the aim of future studies.

\section{CD27 $^{+} \lg M^{+} \operatorname{lgD}{ }^{+}$AND CD27 ${ }^{+} \lg M^{+} \lg D^{-}$MEMORY B CELLS}

In the late 1990s, studies reporting a large proportion of $\mathrm{CD}^{+} 7^{+}$ B cells that have undergone SHM, but not Ig isotype switching, provided support for the existence of $\operatorname{IgM}^{+}$memory $\mathrm{B}$ cells (Klein et al., 1997; Tangye et al., 1998). Further investigations led to the subdivision of this population by describing the $\mathrm{CD}_{27}{ }^{+} \mathrm{IgM}^{+} \mathrm{IgD}^{-}$(IgM-only) and $\mathrm{CD} 27^{+} \mathrm{IgM}^{+} \mathrm{IgD}^{+}$subsets (Klein et al., 1997, 1998a; Weller et al., 2001). A recent study based on the analysis of replication history, SHM, and CSR has shown that IgM-only B cells derive from early GC reactions, whereas $\mathrm{CD}^{2} 7^{+} \mathrm{IgM}^{+} \mathrm{IgD}^{+}$memory B cells have in part a GC-independent origin (Berkowska et al., 2011).

It has been observed that $\mathrm{CD} 27^{+} \mathrm{IgM}^{+} \mathrm{IgD}^{+} \mathrm{B}$ cells correspond to splenic marginal zone $\mathrm{B}$ cells by CDR3 spectratyping and geneexpression profile analysis (Weller et al., 2004). Developmental diversification of these cells has been demonstrated in environments lacking GCs, T-dependent (TD) antigen response, and prior to T-independent (TI) pathway in young children (Weller et al., 2008). These somatically mutated $\mathrm{CD}_{2} 7^{+} \mathrm{IgM}^{+} \mathrm{IgD}^{+} \mathrm{B}$ cells are present in patients that lack GC formation due to CD40 or CD40L deficiency, meaning classical isotype-switched and IgM-only B cell populations are absent (Agematsu et al., 1998b; Weller et al., 2001). Functionally, $\mathrm{CD}_{27}{ }^{+} \mathrm{IgM}^{+} \mathrm{IgD}^{+}$memory cells appear to play a role in response to $\mathrm{TI}$ antigens, most notably the response to encapsulated bacteria. However, they do seem to maintain the capacity to participate in TD responses (Kruetzmann et al., 2003; Weller et al., 2004).

\section{Ig M+ MEMORY CELLS}

\section{T-DEPENDENT VERSUS T-INDEPENDENT MEMORY}

Classically it has been thought that memory B cells are generated in GC in response to TD antigens. Within the GC, the antigenspecific cells are selected and undergo SHM to improve the affinity for antigen. TD antigens are classically proteins and the T cell help is necessary to elicit an antibody response (Vallé et al., 1989; Agematsu et al., 1995). In contrast, T-independent (TI) antigens, such as polysaccharides, can elicit a response without $\mathrm{T}$ cell help. The concept of TI B cell memory has been counter to B cell memory dogma for a long time. Initially, it was assumed that TI antigens do not elicit an amplified and affinity-matured antibody response upon secondary immunization (Defrance et al., 2011). However, recent studies in mice demonstrated TI memory as longlived, anti-bacterial humoral immunity by adoptive transfer of $\mathrm{B}$ cells from mice that had cleared a $B$. hermsii infection into naïve recipients (Alugupalli et al., 2004). The analysis of mouse B cell populations showed that $\mathrm{B} 1-\mathrm{b}$ cells are the source of the memory cells (Alugupalli et al., 2004). The existence of TI memory cells has also been confirmed with the presence of a pool of quiescent, antigen-specific B cells 120 days after immunization (Obukhanych and Nussenzweig, 2006).

\section{HUMAN B1 CELL POPULATIONS}

In mice, B cells are divided into B1 cells (B1-a and B1-b) and B2 cells (follicular cells and marginal zone cells). B1 and marginal zone (MZ) B cells are innate-like B cells that secrete natural antibodies rapidly in response to infections or tissue injury. The development of B1 cells and their response patterns against antigen have been recently reviewed by Baumgarth (2011). Differences in responses to pathogens between the two related populations reside mainly in the BCR activation. Indeed, in response to various stimuli (S. pneumonia, certain carbohydrates, LPS, and certain cytokines) both B1-a and B1-b cells respond with secretion of polyreactive IgM antibodies (IgA is also possible in the gut), a low level of cell proliferation, and no apparent BCR signaling (Nisitani et al., 1995; Ohdan et al., 2000; Martin et al., 2001). In contrast, following 
repeated exposure to TI antigens, only B1-b cells can expand clonally, driven by BCR signaling, and secrete antigen-specific IgM antibodies as a memory response (Defrance et al., 2011).

The existence of B1 cells in humans is controversial; various studies have provided evidence of populations that appear to be similar to the mouse B1 phenotypes, but B1-a and B1b populations per se still lack definition (Griffin et al., 2011). However, polysaccharide vaccines (TI antigens), such as Pneumovax, confer long-term humoral protection in adult humans, suggesting possible TI memory in humans (Lesinski and Westerink, 2001). Notably, however, unlike the antibody genes of typical T-independent responses in mice, the Pneumovax vaccine induces B cells with highly mutated variable genes, similar to $\mathrm{T}$ cell dependent responses (Smith et al., 2009). However, it is impossible to say by this study alone whether these cells obtained their somatic mutations solely through the interaction with the TI antigen alone or whether the cells that were stimulated arose from an already somatically mutated TD memory population; more work must be done here to definitively resolve this issue. There is still considerable debate concerning the function of $\operatorname{IgM}^{+}$memory B cells as human B1 cells. However, there is evidence that $\operatorname{IgM}^{+}$memory B cells are implicated in response to both TI and TD antigens (Tangye and Good, 2007). It is important to note that the recently realized heterogeneity of this population may explain the complexity in their function.

\section{THE DUAL ROLE OF IgM+ MEMORY CELLS: T-INDEPENDENT AND T-DEPENDENT RESPONSES}

We will be defining $\operatorname{IgM}^{+}$memory cells as $\mathrm{CD}^{+} 7^{+} \operatorname{IgM}^{+} \operatorname{IgD}^{ \pm}$as most of the studies do not make the distinction between $\operatorname{IgD}$ expression of $\mathrm{IgM}^{+}$memory B cells. These cells, as mentioned earlier, are implicated primarily in TI responses. First, evidence for human $\operatorname{IgM}^{+}$memory B cells being involved in TI responses is best observed in immunocompromised individuals. $\operatorname{IgM}^{+}$memory cells are reduced in asplenic patients and it is known that these individuals are highly susceptible to infection with encapsulated bacteria (Zandvoort and Timens, 2002; Kruetzmann et al., 2003). A similar phenomenon is also seen in both common variable immunodeficiency (CVID) and elderly patients that lack $\mathrm{IgM}^{+}$ memory cells (Carsetti et al., 2005; Shi et al., 2005). Importantly, in all these cases the susceptibility to encapsulated bacterial infections was heavily dependent on the presence of $\operatorname{IgM}^{+}$memory cells (Kruetzmann et al., 2003; Carsetti et al., 2005; Shi et al., 2005). Second, it appears that specific B cell clones are enriched in the $\mathrm{IgM}^{+}$ memory cell population, residing in the spleen and the peripheral blood of individuals vaccinated against S. pneumonia (Weller et al., 2004). Interestingly, $\operatorname{IgM}^{+}$memory cells are not enriched for broad reactivity against polysaccharide/bacterial antigens; B cells with such specificities are negatively selected before entry into the $\operatorname{IgM}^{+}$memory compartment (Tsuiji et al., 2006). Instead, these $\operatorname{IgM}^{+}$memory B cells recognize specific individual bacterial polysaccharides. These data, taken together, indicate that $\operatorname{IgM}^{+}$ memory B cells are important in specific T-independent responses (Tsuiji et al., 2006).

There is also evidence that $\operatorname{IgM}^{+}$memory cells are involved in responses to TD antigens. In mice, many studies have demonstrated that these memory cells can be generated in response to
TD antigen immunization and strongly support a role of $\operatorname{IgM}^{+}$ memory cells in the secondary response (White and Gray, 2000; Soenawan et al., 2004). In humans, IgM secreting cells can be generated in vitro upon stimulation of memory B cells from individuals vaccinated against TD antigens such as hepatitis $\mathrm{B}$ or in HIV-infected patients (Fondere et al., 2003; Tuaillon et al., 2006). IgM memory cells are also detectable at a low frequency in the memory cell pool weeks after influenza vaccination (Wrammert et al., 2008a). An elegant study furthering this idea used mice transplanted with human B cells subsets and was able to show that both $\operatorname{IgM}^{+}$and switched memory cells can respond to both TD and TI antigens (Moens et al., 2008). Interestingly, in people with hepatitis- $\mathrm{C}$ associated mixed cryoglobulinemia, there are clones of IgM memory cells that are massively expanded and that use predominantly a single variable heavy chain gene, VH1-69 (Charles et al., 2008, 2011). A recent based on global geneexpression analysis and cellular assays in humans have proposed to identify mechanisms that contribute to qualitative differences between primary and secondary humoral responses (Good et al., 2009). $\operatorname{IgM}^{+}$and switched memory cells were compared; it was observed that all memory B cells were found to have high expression of activation and pro-survival molecules such as B7, TNF receptor, SLAM, Bcl2, and CD180 (Good et al., 2009). This is consistent with the ability of the memory cells to respond quickly and to form a pool of cells that persist after an immune response (Good et al., 2009). Perhaps some of the most compelling evidence for this idea comes from recent work, previously described, indicating that $\mathrm{IgM}^{+}$memory B cells are typically the cells to reinitiate specific GC responses to antigen upon secondary challenge (Dogan et al., 2009; Pape et al., 2011). In order to resolve the origin of these $\mathrm{IgM}^{+}$memory cells, Seifert and Kuppers (2009) analyzed the $B c l 6$ mutational level as a marker of GC experience. The authors found that the $\operatorname{IgM}^{+}$memory cells seem to arise from the same GC reactions that are producing class-switched memory B cells, but simply exiting earlier (Seifert and Kuppers, 2009). This data strongly points to the TD origin of IgM memory cells.

These data indicate that $\operatorname{IgM}^{+}$memory B cells have seemingly multiple roles in an immune response. This effect appears to depend greatly on the pathogen and the antigens that are exposed to the immune system. More work must be done to tease apart these two very different mechanisms for B cell response in, paradoxically, what appears to be the same memory compartment. The understanding of how these $\operatorname{IgM}^{+} \mathrm{B}$ cell populations affect an active immune response is in its infancy; the recent data is just beginning to delineate how $\operatorname{IgM}^{+}$B cell populations differ from switched memory cells. It is possible that these studies will lead to a much more structured and elegant picture of the immune response that had previously not existed.

\section{"FOOL ME ONCE. ..": MEMORY RESPONSES TO INFECTIOUS AGENTS AND VACCINES}

In theory, memory B cell compartments to a pathogen or vaccination should all be long-lived responses that can be called upon after the initial challenge to counter secondary exposure to the insult. However, instead of observing this type of response in all cases; memory responses appear to be much more heterogeneous. 
This is likely due to diverse subsets that can be called upon during an immune response, for better or worse.

\section{PERSISTENT MEMORY RESPONSES}

An important property of memory B cells is their ability to be long-lived. The ability to survive in the peripheral blood after activation allows the host to rapidly respond to a recurrent challenge in both kinetics and strength of response; as these cells have already undergone affinity maturation and are primed for quick response (Engels et al., 2009). Remarkably, these long-lived memory B cells have the potential to be sustained in the peripheral blood for decades following initial exposure to an immunological insult. The generation of long-lived memory is the cornerstone of modern vaccination. Arguably, the one of the greatest victories in the field of vaccination was the eradication of the smallpox virus in 1980 (Pennington, 2003). This feat was made possible by the life-long immunity to the virus created by the vaccine. Studies analyzing the human response to the vaccine have shown that childhood vaccination to the disease allows the patient to produce smallpox specific B cells decades after the last appearance of the disease in nature (Crotty et al., 2003, 2004; Hammarlund et al., 2003). These studies demonstrate the persistence of a proper vaccine response even after the antigen has long since disappeared from the earth (Crotty et al., 2003, 2004; Hammarlund et al., 2003). Long-lived CD $27^{+}$memory B cell responses have also been seen for Varicella Zoster virus and measles virus decades following initial vaccination (Pinna et al., 2009).

It has been theorized that a persistent population of specific memory B cells could lead to long-lived antibody titers through the stimulation of these memory cells by polyclonal means, such as CpG DNA and T cell cytokines; suggesting that a response to a polyclonal stimulus can cause the polyclonal activation of memory cells each with their own unique specificity, replenishing the plasma cell populations sporadically over the course of a lifetime without the requirement of specific antigenic stimulation (Bernasconi et al., 2002). If this theory is true it would help to dovetail the two ideas of long-lived memory B cells that do not require antigenic stimulation, and plasma cells, which are producing protective antibody titers over the course of a lifetime of the host; pointing to the importance of driving not only plasma cell formation but long-lived memory B cells for proper vaccine efficacy.

\section{MEMORIES BLUR}

Interestingly, other common vaccinations, such as the influenza vaccination, have been seen to provide mixed results in the generation of long-term B cell memory. While the efficacy of the vaccine is dependent on the correct design of the yearly cocktail and immunity to future strains is dependent on antigenic drift and antigenic shift of the virus, $\mathrm{CD} 27^{+}$memory $\mathrm{B}$ cell persistence to the virus seems to be variable depending on the vaccinating strain (Ahmed et al., 2007; Pinna et al., 2009). Nonetheless, through analysis of the variable gene repertoire we have noted that plasmablasts induced immediately after influenza vaccination (Wrammert et al., 2008a,b) or infection (Wrammert et al., 2011) appear to be predominantly activated from pre-existing memory cells. The antibody efficacy was profoundly affected by this re-induction of memory B cells in that the antigenically similar annual strains predominantly activated B cells to epitopes that were conserved but not protective because selective pressure had induced these protective epitopes to drift (Wrammert et al., 2008a,b). Conversely, infection with the highly divergent pandemic influenza strain in 2009 activated memory cells as well, but in this case they were binding to conserved epitopes that were present because they are critical for viral function or virulence, leading to a predominantly protective response (Wrammert et al., 2011). These observations demonstrate that by targeting particular memory cells for reactivation, a better influenza vaccine might be developed that could protect against most or all influenza strains.

Reports have indicated the discovery of influenza-specific memory B cells to the 1918 pandemic flu almost 100 years following initial exposure to the virus (Yu et al., 2008). Conversely, work on memory responses to influenza vaccination to A/Texas/36/91 Hemagglutinin (HA) were assayed in several patients from 1993 to 2006 and showed that levels of memory B cells specific to this viral HA were ultimately lost by their final time point (Pinna et al., 2009). It is difficult to say what might be attributing to this difference, it could be the variable conditions between live infection and vaccination or it could be a condition of constant exposure to slightly different strains each year.

Currently, work has been very limited in regard to the persistence of influenza-specific memory, but there have been studies on the elderly populations' responses to novel 2009 pandemic $\mathrm{H} 1 \mathrm{~N} 1$ (Sasaki et al., 2011). Epidemiological data collected from the 2009 pandemic that indicated that the best protected population against the pandemic influenza were born prior to 1957; being born after this time point is associated with decreasing protection as births approach present day (Fisman et al., 2009). In a recent study, elderly populations were examined for their specific responses to either their vaccinating antigen, 2009 seasonal $\mathrm{H} 1 \mathrm{~N} 1$, or to the non-vaccinating antigen, novel 2009 pandemic H1N1 (Sasaki et al., 2011). It was seen that both groups responded equally well to the vaccinating antigen, but only the elderly patients showed increased cross-reactivity to a non-vaccinating pandemic $\mathrm{H} 1 \mathrm{~N} 1$ strain (Sasaki et al., 2011). It is thought that these differences, both epidemiologically and experimentally, derive from elderly populations' increased exposure to influenza viruses over the course of their lives, leading to more robust memory B cell response (Fisman et al., 2009; Sasaki et al., 2011).

These recent studies provide insights into how our bodies maintain memory B cell populations over the course of time in the presence of constant antigen exposure, as in the case of influenza, or when antigen is no longer present, as with the smallpox vaccine.

\section{WANING IMMUNE RESPONSE TO VACCINES: THE IMPORTANCE OF MEMORY B CELLS}

Human licensed vaccines can be subdivided into two groups concerning their ability to maintain specific antibody levels: vaccines that elicit long-term, stable antibody production, like the smallpox vaccine discussed earlier, and vaccines that do not. Designed to combat the disease caused by the spore-forming bacteria Bacillus anthracis, the Anthrax Vaccine Adsorbed (AVA or BioThrax; Ivins and Welkos, 1988) is one of these vaccines. Unlike most successful vaccines that require only one to three boosts to acquire 


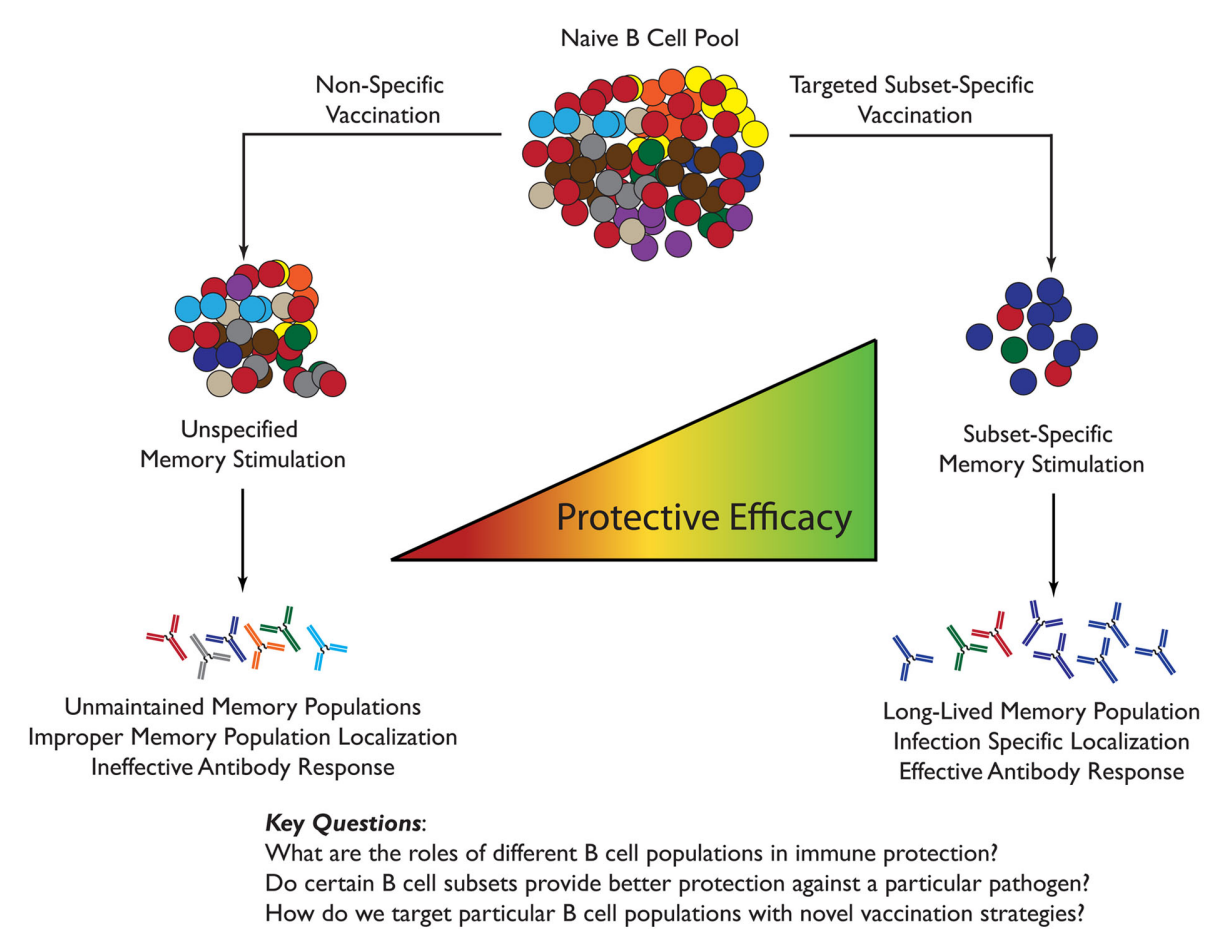

FIGURE 1 | Specifically targeted memory B cell subset versus non-targeted vaccination. (Above) A conceptual cartoon displaying the benefits of designing a vaccination with a particular $B$ memory cell subset targeted. The vaccine would be greatly dependent on the pathogen of interest and route of infection. To prime the most effective B memory subset the type of antigen and adjuvant must be rationally chosen based on the known properties of the subset. By targeting a particular memory B cell subset in a vaccine the localization, type and magnitude of antibody response, and the maintenance of the memory B cell subset populations can be altered to generate an effective antibody response upon subsequent exposure. Conversely, non-specific memory B cell vaccine design can lead to the loss of maintenance and/or establishment of important memory populations, improper response localization, and ineffective antibody response. These factors combined can lead to a loss of efficacy in a vaccine. permanent protective antibody titers, the anthrax vaccine must be boosted repeatedly five times over the first year and then annually to maintain protective titers. As such, it is a good example of a vaccine whose potency appears to wane with time. This vaccine is composed predominantly of protective antigen (PA) that is a key element of the anthrax toxin. Anti-PA IgG antibodies confer protection to different animals challenged with $B$. anthracis (Ivins et al., 1998; Pitt et al., 2001) and the efficacy of AVA immunization is based on quantity and neutralizing capacity of these anti-PA antibodies (Crowe et al., 2010) that increase with successive or recent boosts (Crowe et al., 2011). A study in people vaccinated with the primary series of AVA ( six first doses) demonstrated that the majority of the vaccinated individuals had developed anti-PA IgG antibodies after two to three dosages, however, titers of anti-PA antibody decreased over time (Pittman et al., 2006). The phenomena of anti-PA antibody titer reduction over time has also been observed in studies using rhesus macaques and mice (Ivins et al., 1996; Tross and Klinman, 2008). Importantly, however, upon challenge with $B$. anthracis, a subset of animals exhibiting low or no detectable amounts of PA-reactive sera but were still able to survive and produce PA-reactive Ig (Ivins et al., 1996; Tross and Klinman, 2008). Through work using a CpG adjuvant to attempt to boost the vaccine response it was seen that this effect derived mainly from the B memory compartment (Klinman et al., 2006; Tross and Klinman, 2008). Unlike the unprotected group, the surviving animals had a large population of memory B cells that expressed high affinity, PAspecific antibody (Tross and Klinman, 2008). What is interesting is that these memory cells were only established in a subset of animals, begging the questions posed in Figure 1: how do you target an appropriate memory response? Further, what was unique about the response in protected versus susceptible animals? Because CpG is more of a T-independent adjuvant, could targeting more innate (B1-like) B cell populations induce this improved memory response to a less immunogenic vaccine? It is essential to learn more about the B cell memory response and how it can be targeted or for the establishment of new and more effective vaccines.

\section{CONCLUSION}

The discovery of B memory cell subsets has opened a door into redefining how we understand the establishment of long-term immunological memory. By understanding the diversity of the memory B cell response, we will be better equipped to answer many outstanding questions in disease pathology. We have described situations where both ineffective and effective immune memory responses are generated to infection and vaccination. The acquisition of a proper, effective immune response to a vaccination will require careful planning during vaccine design to best take advantage of the desirable properties of these subsets. To do this, more research must be performed to flesh out the environments that create these subsets and understand their functional properties 
in vivo (Figure 1). It will be crucial to generate clinically relevant means to reverse the effects of ineffective memory responses as therapeutic treatments to ongoing, chronic infections. Much like Jenner and Pasteur using the fundamental idea of immunological memory to formulate strategies in prophylaxis to disease, this powerful idea of the diversity in the memory B cell compartment may make it possible to tear down age-old impediments that have plagued the field of vaccinology; leading to the design of novel and effective treatments to the most stubborn diseases.

\section{REFERENCES}

Agematsu, K., Kobata, T., Yang, F.C., Nakazawa, T., Fukushima, K., Kitahara, M., Mori, T., Sugita, K., Morimoto, C., and Komiyama, A. (1995). CD27/CD70 interaction directly drives B cell IgG and IgM synthesis. Eur. J. Immunol. 25, 2825-2829.

Agematsu, K., Nagumo, H., Oguchi, Y., Nakazawa, T., Fukushima, K., Yasui, K., Ito, S., Kobata, T., Morimoto, C., and Komiyama, A. (1998a). Generation of plasma cells from peripheral blood memory B cells: synergistic effect of interleukin-10 and CD27/CD70 interaction. Blood 91, 173-180.

Agematsu, K., Nagumo, H., Shinozaki, K., Hokibara, S., Yasui, K., Terada, K., Kawamura, N., Toba, T., Nonoyama, S., Ochs, H. D., and Komiyama, A. (1998b). Absence of IgD-CD27(+) memory $\mathrm{B}$ cell population in $\mathrm{X}$ linked hyper-IgM syndrome. J. Clin. Invest. 102, 853-860.

Agematsu, K., Nagumo, H., Yang, F.C., Nakazawa, T., Fukushima, K., Ito, S., Sugita, K., Mori, T., Kobata, T., Morimoto, C., and Komiyama, A. (1997). B cell subpopulations separated by CD27 and crucial collaboration of CD27+ B cells and helper $\mathrm{T}$ cells in immunoglobulin production. Eur. J. Immunol. 27, 2073-2079.

Ahmed, R., Oldstone, M. B. A., and Palese, P. (2007). Protective immunity and susceptibility to infectious diseases: lessons from the 1918 influenza pandemic. Nat. Immunol. 8, 1188-1193.

Alugupalli, K. R., Leong, J. M., Woodland, R. T., Muramatsu, M., Honjo, T., and Gerstein, R. M. (2004). Blb lymphocytes confer $\mathrm{T}$ cellindependent long-lasting immunity. Immunity 21, 379-390.

Amanna, I. J., Carlson, N. E., and Slifka, M. K. (2007). Duration of humoral immunity to common viral and vaccine antigens. N. Engl. J. Med. 357, 1903-1915.

Arpin, C., De Bouteiller, O., Razanajaona, D., Fugier-Vivier, I., Brière, F., Banchereau, J., Lebecque, S., and Liu,
Y.-J. (1998). The normal counterpart of IgD myeloma cells in germinal center displays extensively mutated IgVH gene, $\mathrm{C} \mu-\mathrm{C} \delta$ switch, and $\lambda$ light chain expression. J. Exp. Med. 187, 1169-1178. Merville, P., Grouard, G., Briere, F., Banchereau, J., and Liu, Y. (1995). Generation of memory B cells and plasma cells in vitro. Science 268, 720-722.

Banchereau, J., and Rousset, F. (1991). in the CD40 system. Nature 353, 678-679.

Baumgarth, N. (2011). The double life of a B-1 cell: self-reactivity selects for protective effector functions. Nat. Rev. Immunol. 11, 34-46.

Berkowska, M. A., Driessen, G. J., Bikos, V., Grosserichter-Wagener, C., Stamatopoulos, K., Cerutti, A., He, B., Biermann, K., Lange, J. F., Van Der Burg, M., Van Dongen, J. J., and Van Zelm, M. C. (2011). Human memory B cells originate from three distinct germinal center-dependent and -independent maturation pathways. Blood 118, 2150-2158.

Bernasconi, N. L., Traggiai, E., and Lanzavecchia, A. (2002). Maintenance of serological memory by polyclonal activation of human memory B cells. Science 298, 2199-2202.

Black, S. J., Goding, J. W., Gutman, G. A., Herzenberg, L. A., Loken, M. R., Osborne, B. A., Van Der Loo, W., and Warner, N. L. (1978). Immunoglobulin isoantigens (allotypes) in the mouse : V. Characterization of IgM allotypes. Immunogenetics 7, 213-230.

Bourgois, A., Kitajima, K., Hunter, I. R., and Askonas, B. A. (1977). Surface immunoglobulins of lipopolysaccharide-stimulated spleen cells. The behavior of IgM, IgD and IgG. Eur. J. Immunol. 7, 151-153.

Bowman, M., Crimmins, M., YetzAldape, J., Kriz, R., Kelleher, K., and Herrmann, S. (1994). The cloning of CD70 and its identification as the
Arpin, C., Dechanet, J., Van Kooten, C., Growing human B lymphocytes

\section{ACKNOWLEDGMENTS}

This work was supported by National Institutes of Health (NIH)/National Institute of Allergy and Infectious Diseases (NIAID) grant numbers: 2U54AI057158-06, 2U19AI057266-06, 5U19AI062629-07, 1U19AI082724-02, 1RC4AI092711-01, and U19AI09023-01. This work was also supported by the National Institutes of Health (NIH) and National Institute of Allergy and Infectious Diseases (NIAID) Immunology Training Grant number 5T32AI007090-33.

ligand for CD27. J. Immunol. 152, 1756-1761.

Brokstad, K. A., Cox, R. J., Olofsson, J., Jonsson, R., and Haaheim, L. R. (1995). Parenteral influenza vaccination induces a rapid systemic and local immune response. J. Infect. Dis. 171, 198-203.

Burnet, F. M. (1957). A modification of Jerne's theory of antibody production using the concept of clonal selection. Aust. J. Sci. 20, 67-69.

Cagigi, A., Du, L., Dang, L. V., Grutzmeier, S., Atlas, A., Chiodi, F., Pan-Hammarstrom, Q., and Nilsson, A. (2009). CD27(-) B-cells produce class switched and somatically hyper-mutated antibodies during chronic HIV-1 infection. PLoS ONE 4, e5427. doi:10.1371/journal.pone.0005427

Carsetti, R., Rosado, M. M., Donnanno, S., Guazzi, V., Soresina, A., Meini, A., Plebani, A., Aiuti, F., and Quinti, I. (2005). The loss of IgM memory B cells correlates with clinical disease in common variable immunodeficiency. J. Allergy Clin. Immunol. 115, 412-417.

Charles, E. D., Brunetti, C., Marukian, S., Ritola, K. D., Talal, A. H., Marks, K., Jacobson, I. M., Rice, C. M., and Dustin, L. B. (2011). Clonal $B$ cells in patients with hepatitis C virus-associated mixed cryoglobulinemia contain an expanded anergic CD21low B-cell subset. Blood 117, 5425-5437.

Charles, E. D., Green, R. M., Marukian, S., Talal, A. H., LakeBakaar, G. V., Jacobson, I. M., Rice, C. M., and Dustin, L. B. (2008). Clonal expansion of immunoglobulin $\mathrm{M}+\mathrm{CD} 27+\mathrm{B}$ cells in HCV-associated mixed cryoglobulinemia. Blood 111, 1344-1356.

Chen, K., Xu, W., Wilson, M., He, B., Miller, N. W., Bengten, E., Edholm, E.-S., Santini, P. A., Rath, P., Chiu, A., Cattalini, M., Litzman, J., Bussel, J., Huang, B., Meini, A., Riesbeck, K., CunninghamRundles, C., Plebani, A., and Cerutti, A. (2009). Immunoglobulin D enhances immune surveillance by activating antimicrobial, proinflammatory and B cell-stimulating programs in basophils. Nat. Immunol. 10, 889-898.

Crotty, S., Aubert, R. D., Glidewell, J., and Ahmed, R. (2004). Tracking human antigen-specific memory B cells: a sensitive and generalized ELISPOT system. J. Immunol. Methods 286, 111-122.

Crotty, S., Felgner, P., Davies, H., Glidewell, J., Villarreal, L., and Ahmed, R. (2003). Cutting edge: long-term B cell memory in humans after smallpox vaccination. J. Immunol. 171, 4969-4973.

Crowe, S. R., Ash, L. L., Engler, R. J., Ballard, J. D., Harley, J. B., Farris, A. D., and James, J. A. (2010). Select human anthrax protective antigen epitope-specific antibodies provide protection from lethal toxin challenge. J. Infect. Dis. 202, 251-260.

Crowe, S. R., Garman, L., Engler, R. J., Farris, A. D., Ballard, J. D., Harley, J. B., and James, J. A. (2011). Anthrax vaccination induced antilethal factor IgG: fine specificity and neutralizing capacity. Vaccine 29, 3670-3678.

Day, C. L., Kaufmann, D. E., Kiepiela, P., Brown, J. A., Moodley, E. S., Reddy, S., Mackey, E. W., Miller, J. D., Leslie, A. J., Depierres, C., Mncube, Z., Duraiswamy, J., Zhu, B., Eichbaum, Q., Altfeld, M., Wherry, E. J., Coovadia, H. M., Goulder, P. J., Klenerman, P., Ahmed, R., Freeman, G. J., and Walker, B. D. (2006). PD-1 expression on HIV-specific T cells is associated with T-cell exhaustion and disease progression. Nature 443, 350-354.

Defrance, T., Taillardet, M., and Genestier, L. (2011). T cell-independent B cell memory. Curr. Opin. Immunol. 23, 330-336.

Dogan, I., Bertocci, B., Vilmont, V., Delbos, F., Megret, J., Storck, S., Reynaud, C.-A., and Weill, J.C. (2009). Multiple layers of B cell memory with different effector functions. Nat. Immunol. 10, 1292-1299. 
Early, P., Rogers, J., Davis, M., Calame, K., Bond, M., Wall, R., and Hood, L. (1980). Two mRNAs can be produced from a single immunoglobulin $\mu$ gene by alternative RNA processing pathways. Cell 20, 313-319.

Ehrhardt, G. R., Davis, R. S., Hsu, J. T., Leu, C. M., Ehrhardt, A., and Cooper, M. D. (2003). The inhibitory potential of Fc receptor homolog 4 on memory B cells. Proc. Natl. Acad. Sci. U.S.A. 100, 13489-13494.

Ehrhardt, G. R., Hijikata, A., Kitamura, H., Ohara, O., Wang, J. Y., and Cooper, M. D. (2008). Discriminating gene expression profiles of memory B cell subpopulations. J. Exp. Med. 205, 1807-1817.

Ehrhardt, G. R., Hsu, J. T., Gartland, L., Leu, C. M., Zhang, S., Davis, R. S., and Cooper, M. D. (2005). Expression of the immunoregulatory molecule FcRH4 defines a distinctive tissue-based population of memory B cells. J. Exp. Med. 202, 783-791.

Eisenbarth, G. S., Haynes, B. F., Schroer, J. A., and Fauci, A. S. (1980). Production of monoclonal antibodies reacting with peripheral blood mononuclear cell surface differentiation antigens. J. Immunol. 124, 1237-1244.

Engels, N., Konig, L. M., Heemann, C., Lutz, J., Tsubata, T., Griep, S., Schrader, V., and Wienands, J. (2009). Recruitment of the cytoplasmic adaptor Grb2 to surface IgG and IgE provides antigen receptorintrinsic costimulation to classswitched B cells. Nat. Immunol. 10, 1018-1025.

Falini, B., Tiacci, E., Pucciarini, A., Bigerna, B., Kurth, J., Hatzivassiliou, G., Droetto, S., Galletti, B. V., Gambacorta, M., Orazi, A., Pasqualucci, L., Miller, I., Küppers, R., DallaFavera, R., and Cattoretti, G. (2003). Expression of the IRTA1 receptor identifies intraepithelial and subepithelial marginal zone B cells of the mucosa-associated lymphoid tissue (MALT). Blood 102, 3684-3692.

Fecteau, J. F., Cote, G., and Neron, S. (2006). A new memory CD27-IgG+ B cell population in peripheral blood expressing $\mathrm{VH}$ genes with low frequency of somatic mutation. J. Immunol. 177, 3728-3736.

Fisman, D. N., Savage, R., Gubbay, J., Achonu, C., Akwar, H., Farrell, D. J., Crowcroft, N. S., and Jackson, P. (2009). Older age and a reduced likelihood of $2009 \mathrm{H} 1 \mathrm{~N} 1$ virus infection. New Engl. J. Med. 361, 2000-2001.

Fondere, J. M., Huguet, M. F., Yssel, H., Baillat, V., Reynes, J., Van De Perre, P., and Vendrell, J. P. (2003). Detection of peripheral HIV-1specific memory B cells in patients untreated or receiving highly active antiretroviral therapy. AIDS 17, 2323-2330.

Good, K. L., Avery, D. T., and Tangye, S. G. (2009). Resting human memory B cells are intrinsically programmed for enhanced survival and responsiveness to diverse stimuli compared to naive B cells. J. Immunol. 182, 890-901.

Griffin, D. O., Holodick, N. E., and Rothstein, T. L. (2011). Human B1 cells in umbilical cord and adult peripheral blood express the novel phenotype CD20+CD27+CD43+CD70-. J. Exp. Med. 208, 67-80.

Hammarlund, E., Lewis, M. W., Hansen, S. G., Strelow, L. I., Nelson, J. A., Sexton, G. J., Hanifin, J. M., and Slifka, M. K. (2003). Duration of antiviral immunity after smallpox vaccination. Nat. Med. 9, 1131-1137.

Haynes, N. M., Allen, C. D. C., Lesley, R., Ansel, K. M., Killeen, N., and Cyster, J. G. (2007). Role of CXCR5 and CCR7 in Follicular Th cell positioning and appearance of a programmed cell death genelhigh germinal center-associated subpopulation. J. Immunol. 179, 5099-5108.

Hebeis, B. J., Klenovsek, K., Rohwer, P., Ritter, U., Schneider, A., Mach, M., and Winkler, T. H. (2004). Activation of virus-specific memory B cells in the absence of T cell help. J. Exp. Med. 199, 593-602.

Ivins, B. E., Fellows, P. F., Pitt, M. L. M., Estep, J. E., Welkos, S. L., Worsham, P. L., and Friedlander, A. M. (1996). "Efficacy of a standard human anthrax vaccine against Bacillus anthracis aerosol spore challenge in rhesus monkeys," in Proceedings of the International Workshop on Anthrax, Winchester.

Ivins, B. E., Pitt, M. L., Fellows, P. F., Farchaus, J. W., Benner, G. E., Waag, D. M., Little, S. F., Anderson, G. W. Jr., Gibbs, P. H., and Friedlander, A. M. (1998). Comparative efficacy of experimental anthrax vaccine candidates against inhalation anthrax in rhesus macaques. Vaccine 16, 1141-1148.

Ivins, B. E., and Welkos, S. L. (1988). Recent advances in the development of an improved, human anthrax vaccine. Eur. J. Epidemiol. 4, 12-19.

Jaiswal, A. I., and Croft, M. (1997). CD40 ligand induction on T cell subsets by peptide-presenting B cells: implications for development of the primary $\mathrm{T}$ and $\mathrm{B}$ cell response. $J$. Immunol. 159, 2282-2291.

Junt, T., Moseman, E. A., Iannacone, M., Massberg, S., Lang, P. A., Boes, M., Fink, K., Henrickson, S. E.,
Shayakhmetov, D. M., Di Paolo, N. C., Van Rooijen, N., Mempel, T. R. Whelan, S. P., and Von Andrian, U. H. (2007). Subcapsular sinus macrophages in lymph nodes clear lymph-borne viruses and present them to antiviral B cells. Nature 450, 110-114.

Kardava, L., Moir, S., Wang, W., Ho, J., Buckner, C. M., Posada, J. G., O'Shea, M. A., Roby, G., Chen, J., Sohn, H. W., Chun, T. W., Pierce, S. K., and Fauci, A. S. (2011). Attenuation of HIV-associated human B cell exhaustion by siRNA downregulation of inhibitory receptors. J. Clin. Invest. 121, 2614-2624.

Kearney, J. F. (2005). Innate-like B cells. Springer Semin. Immunopathol. 26, 377-383.

Kinashi, T., Godal, T., Noma, Y., Ling, N. R., Yaoita, Y., and Honjo, T (1987). Human neoplastic B cells express more than two isotypes of immunoglobulins without deletion of heavy-chain constant-region genes. Genes Dev. 1, 465-470.

Kincade, P. W., Lawton, A. R., Bockman, D. E., and Cooper, M. D. (1970). Suppression of immunoglobulin $G$ synthesis as a result of antibody-mediated suppression of immunoglobulin M synthesis in chickens. Proc. Natl. Acad. Sci. U.S.A. 67, 1918-1925.

Klein, U., Kuppers, R., and Rajewsky, K. (1997). Evidence for a large compartment of IgM-expressing memory B cells in humans. Blood 89 , 1288-1298.

Klein, U., Rajewsky, K., and Kuppers, R. (1998a). Human immunoglobulin (Ig) $\mathrm{M}+\mathrm{IgD}+$ peripheral blood B cells expressing the CD27 cell surface antigen carry somatically mutated variable region genes: CD27 as a general marker for somatically mutated (memory) B cells. J. Exp. Med. 188, 1679-1689.

Klein, U., Rajewsky, K., and Küppers, R. (1998b). Human immunoglobulin $(\mathrm{Ig}) \mathrm{M}+\mathrm{IgD}+$ peripheral blood $\mathrm{B}$ cells expressing the CD27 cell surface antigen carry somatically mutated variable region genes: CD27 as a general marker for somatically mutated (memory) B cells. J. Exp. Med. 188, 1679-1689.

Klinman, D. M., Xie, H., and Ivins, B. E. (2006). CpG oligonucleotides improve the protective immune response induced by the licensed anthrax vaccine. Ann. N. Y. Acad. Sci. 1082, 137-150.

Klinman, N. R., and Doughty, R. A. (1973). Hapten-specific stimulation of secondary B cells independent of T cells. J. Exp. Med. 138, 473-478.
Koelsch, K., Zheng, N.-Y., Zhang, Q., Duty, A., Helms, C., Mathias, M. D. Jared, M., Smith, K., Capra, J. D., and Wilson, P. C. (2007). Mature B cells class switched to IgD are autoreactive in healthy individuals. J. Clin. Invest. 117, 1558-1565.

Kruetzmann, S., Rosado, M. M., Weber, H., Germing, U., Tournilhac, O., Peter, H. H., Berner, R., Peters, A., Boehm, T., Plebani, A., Quinti, I., and Carsetti, R. (2003). Human immunoglobulin M memory B cells controlling Streptococcus pneumoniae infections are generated in the spleen. J. Exp. Med. 197, 939-945.

Lanzavecchia, A. (1990). Receptormediated antigen uptake and its effect on antigen presentation to class II-restricted T lymphocytes. Annu. Rev. Immunol. 8, 773-793.

Lesinski, G. B., and Westerink, M. A. (2001). Novel vaccine strategies to Tindependent antigens. J. Microbiol. Methods 47, 135-149.

Liu, Y.-J., Barthélémy, C., Bouteiller, O. D., Arpin, C., Isabelle, D., and Banchereau, J. (1995). Memory B cells from human tonsils colonize mucosal epithelium and directly present antigen to $T$ cells by rapid up-regulation of B7-1 and B7-2. Immunity 2, 239-248.

Liu, Y.-J., De Bouteiller, O., Arpin, C., Brière, F., Galibert, L., Ho, S., Martinez-Valdez, H., Banchereau, J., and Lebecque, S. (1996). Normal human IgD+IgM- germinal center B cells can express up to 80 mutations in the variable region of their IgD transcripts. Immunity 4, 603-613.

Liu, Y. J., Joshua, D. E., Williams, G. T., Smith, C. A., Gordon, J., and Maclennan, I. C. M. (1989). Mechanism of antigen-driven selection in germinal centres. Nature 342, 929-931.

Liu, Y.-J., Mason, D. Y., Johnson, G. D., Abbot, S., Gregory, C. D., Hardie, D. L., Gordon, J., and Maclennan, I. C. M. (1991a). Germinal center cells express bcl-2 protein after activation by signals which prevent their entry into apoptosis. Eur. J. Immunol. 21, 1905-1910.

Liu, Y.-J., Zhang, J., Lane, P. J. L., Chan, E. Y. T., and Maclennan, I. C. M. (1991b). Sites of specific B cell activation in primary and secondary responses to $\mathrm{T}$ cell-dependent and T cell-independent antigens. Eur. J. Immunol. 21, 2951-2962.

Martin, F., Oliver, A. M., and Kearney, J. F. (2001). Marginal zone and B1 $B$ cells unite in the early response against T-independent blood-borne particulate antigens. Immunity 14, 617-629. 
Maurer, D., Fischer, G., Fae, I., Majdic, O., Stuhlmeier, K., Von Jeney, N., Holter, W., and Knapp, W. (1992). IgM and IgG but not cytokine secretion is restricted to the $\mathrm{CD} 27+\mathrm{B}$ lymphocyte subset. J. Immunol. 148, 3700-3705.

Maurer, D., Holter, W., Majdic, O., Fischer, G. F., and Knapp, W. (1990). CD27 expression by a distinct subpopulation of human B lymphocytes. Eur. J. Immunol. 20, 2679-2684.

Miller, I., Hatzivassiliou, G., Cattoretti, G., Mendelsohn, C., and DallaFavera, R. (2002). IRTAs: a new family of immunoglobulinlike receptors differentially expressed in B cells. Blood 99, 2662-2669.

Moens, L., Wuyts, M., Meyts, I., De Boeck, K., and Bossuyt, X. (2008). Human memory B lymphocyte subsets fulfill distinct roles in the anti-polysaccharide and anti-protein immune response. $J$. Immunol. 181, 5306-5312.

Moir, S., Ho, J., Malaspina, A., Wang, W., Dipoto, A. C., O’Shea, M. A., Roby, G., Kottilil, S., Arthos, J., Proschan, M. A., Chun, T. W., and Fauci, A. S. (2008). Evidence for HIV-associated $B$ cell exhaustion in a dysfunctional memory B cell compartment in HIV-infected viremic individuals. J. Exp. Med. 205, 1797-1805.

Moller, G., and Wigzell, H. (1965). Antibody Synthesis at the cellular level. antibody-induced suppression of $19 \mathrm{~s}$ and $7 \mathrm{~s}$ antibody response. $J$. Exp. Med. 121, 969-989.

Montoya, M. C., Holtmann, K., Snapp, K. R., Borges, E., Sánchez-Madrid, F., Luscinskas, F. W., Kansas, G., Vestweber, D., and De Landázuri, M. O. (1999). Memory B lymphocytes from secondary lymphoid organs interact with E-selectin through a novel glycoprotein ligand. J. Clin. Invest. 103, 1317-1327.

Moore, K. W., Rogers, J., Hunkapiller, T., Early, P., Nottenburg, C., Weissman, I., Bazin, H., Wall, R., and Hood, L. E. (1981). Expression of IgD may use both DNA rearrangement and RNA splicing mechanisms. Proc. Natl. Acad. Sci. U.S.A. 78, 1800-1804.

Morgan, A. J., and Parker, S. (2007). Translational mini-review series on vaccines: the Edward Jenner museum and the history of vaccination. Clin. Exp. Immunol. 147, 389-394.

Muramatsu, M., Kinoshita, K., Fagarasan, S., Yamada, S., Shinkai, Y., and Honjo, T. (2000). Class switch recombination and hypermutation require activation-induced cytidine deaminase (AID), a potential
RNA editing enzyme. Cell 102, 553-563.

Nieuwenhuis, P., and Opstelten, D. (1984). Functional anatomy of germinal centers. Am. J. Anat. 170, 421-435.

Nisitani, S., Tsubata, T., Murakami, M., and Honjo, T. (1995). Administration of interleukin-5 or -10 activates peritoneal $\mathrm{B}-1$ cells and induces autoimmune hemolytic anemia in anti-erythrocyte autoantibody-transgenic mice. Eur. J. Immunol. 25, 3047-3052.

Obukhanych, T. V., and Nussenzweig, M. C. (2006). T-independent type II immune responses generate memory B cells. J. Exp. Med. 203, 305-310.

Ohdan, H., Swenson, K. G., Kruger Gray, H. S., Yang, Y. G., Xu, Y., Thall, A. D., and Sykes, M. (2000). Mac-1-negative B-1b phenotype of natural antibody-producing cells, including those responding to $\mathrm{Gal}$ alpha $1,3 \mathrm{Gal}$ epitopes in alpha 1,3galactosyltransferase-deficient mice. J. Immunol. 165, 5518-5529.

Okada, T., Miller, M. J., Parker, I., Krummel, M. F., Neighbors, M., Hartley, S. B., O'Garra, A., Cahalan, M. D., and Cyster, J. G. (2005). Antigenengaged $B$ cells undergo chemotaxis toward the $\mathrm{T}$ zone and form motile conjugates with helper $\mathrm{T}$ cells. PLoS Biol. 3, e150. doi:10.1371/journal.pbio.0030150

Pape, K. A., Taylor, J. J., Maul, R. W., Gearhart, P. J., and Jenkins, M. K. (2011). Different B cell populations mediate early and late memory during an endogenous immune response. Science 331, 1203-1207.

Pascual, V., Liu, Y. J., Magalski, A., De Bouteiller, O., Banchereau, J., and Capra, J. D. (1994). Analysis of somatic mutation in five B cell subsets of human tonsil. J. Exp. Med. 180, 329-339.

Pascual, V., Victor, K., Lelsz, D., Spellerberg, M., Hamblin, T., Thompson, K., Randen, I., Natvig, J., Capra, J., and Stevenson, F. (1991). Nucleotide sequence analysis of the $\mathrm{V}$ regions of two IgM cold agglutinins. Evidence that the VH4-21 gene segment is responsible for the major crossreactive idiotype. J. Immunol. 146, 4385-4391.

Pascual, V., Victor, K., Spellerberg, M., Hamblin, T., Stevenson, F., and Capra, J. (1992). VH restriction among human cold agglutinins. The VH4-21 gene segment is required to encode anti-I and anti-i specificities. J. Immunol. 149, 2337-2344.

Pasteur, M. (1881a). An address on vaccination in relation to chicken cholera and splenic fever. $\mathrm{Br}$. Med. J. 2, 283-284.
Pasteur, M. L. (1881b). On chicken cholera: study of the conditions of non-recidivation and of some other characteristics of this disease. Science 2, 55-57.

Pennington, H. (2003). Smallpox and bioterrorism. Bull. World Health Organ. 81, 762-767.

Phan, T. G., Green, J. A., Gray, E. E., Xu, Y., and Cyster, J. G. (2009). Immune complex relay by subcapsular sinus macrophages and noncognate B cells drives antibody affinity maturation. Nat. Immunol. 10, 786-793.

Pinna, D., Corti, D., Jarrossay, D., Sallusto, F., and Lanzavecchia, A. (2009). Clonal dissection of the human memory B-cell repertoire following infection and vaccination. Eur. J. Immunol. 39, 1260-1270.

Pitt, M. L., Little, S. F., Ivins, B. E., Fellows, P., Barth, J., Hewetson, J., Gibbs, P., Dertzbaugh, M., and Friedlander, A. M. (2001). In vitro correlate of immunity in a rabbit model of inhalational anthrax. Vaccine 19, 4768-4773.

Pittman, P. R., Norris, S. L., Barrera Oro, J. G., Bedwell, D., Cannon, T. L., and Mckee, K. T. Jr. (2006). Patterns of antibody response in humans to the anthrax vaccine adsorbed (AVA) primary (six-dose) series. Vaccine 24, 3654-3660.

Pugh-Bernard, A. E., Silverman, G. J., Cappione, A. J., Villano, M. E., Ryan, D. H., Insel, R. A., and Sanz, I. (2001). Regulation of inherently autoreactive VH4-34 B cells in the maintenance of human B cell tolerance. $J$. Clin. Invest. 108, 1061-1070.

Revy, P., Muto, T., Levy, Y., Geissmann, F., Plebani, A., Sanal, O., Catalan, N., Forveille, M., Dufourcq-Lagelouse, R., Gennery, A., Tezcan, I., Ersoy, F., Kayserili, H., Ugazio, A. G., Brousse, N., Muramatsu, M., Notarangelo, L. D., Kinoshita, K., Honjo, T., Fischer, A., and Durandy, A. (2000). Activation-induced cytidine deaminase (AID) deficiency causes the autosomal recessive form of the hyper-IgM syndrome (HIGM2). Cell 102, 565-575.

Sasaki, S., Sullivan, M., Narvaez, C. F., Holmes, T. H., Furman, D., Zheng, N.-Y., Nishtala, M., Wrammert, J., Smith, K., James, J. A., Dekker, C. L., Davis, M. M., Wilson, P. C., Greenberg, H. B., and He, X.-S. (2011). Limited efficacy of inactivated influenza vaccine in elderly individuals is associated with decreased production of vaccinespecific antibodies. J. Clin. Invest. 121, 3109-3119.

Schwickert, T. A., Victora, G. D., Fooksman, D. R., Kamphorst, A. O., Mugnier, M. R., Gitlin, A.
D., Dustin, M. L., and Nussenzweig, M. C. (2011). A dynamic $\mathrm{T}$ cell-limited checkpoint regulates affinity-dependent B cell entry into the germinal center. J. Exp. Med. 208, 1243-1252.

Seifert, M., and Kuppers, R. (2009). Molecular footprints of a germinal center derivation of human $\mathrm{IgM}+(\mathrm{IgD}+) \mathrm{CD} 27+\mathrm{B}$ cells and the dynamics of memory B cell generation. J. Exp. Med. 206, 2659-2669.

Seifert, M., Steimle-Grauer, S. A., Goossens, T., Hansmann, M. L., Brauninger, A., and Kuppers, R. (2009). A model for the development of human IgD-only B cells: genotypic analyses suggest their generation in superantigen driven immune responses. Mol. Immunol. 46, 630-639.

Shi, Y., Yamazaki, T., Okubo, Y., Uehara, Y., Sugane, K., and Agematsu, K. (2005). Regulation of aged humoral immune defense against pneumococcal bacteria by IgM memory B cell. J. Immunol. 175, 3262-3267.

Smith, K., Garman, L., Wrammert, J., Zheng, N.-Y., Capra, J. D., Ahmed, R., and Wilson, P. C. (2009). Rapid generation of fully human monoclonal antibodies specific to a vaccinating antigen. Nat. Protoc. 4, 372-384.

Snapper, C. M., and Paul, W. E. (1987). Interferon-gamma and B cell stimulatory factor-1 reciprocally regulate Ig isotype production. Science 236, 944-947.

Soenawan, E., Srivastava, I., Gupta, S., Kan, E., Janani, R., Kazzaz, J., Singh, M., Shreedhar, V., and Vajdy, M. (2004). Maintenance of long-term immunological memory by low avidity IgMsecreting cells in bone marrow after mucosal immunizations with cholera toxin adjuvant. Vaccine 22, 1553-1563.

Szakal, A., Kosco, M., and Tew, J. (1988). A novel in vivo follicular dendritic cell-dependent iccosome-mediated mechanism for delivery of antigen to antigen-processing cells. J. Immunol. 140, 341-353.

Talmage, D. W. (1957). Allergy and immunology. Annu. Rev. Med. 8, 239-256.

Tangye, S. G., and Good, K. L. (2007). Human IgM+CD27+ B cells: memory B cells or "memory" B cells? J. Immunol. 179, 13-19.

Tangye, S. G., Liu, Y.-J., Aversa, G., Phillips, J. H., and De Vries, J. E. (1998). Identification of functional human splenic memory B cells by expression of CD148 and CD27. J. Exp. Med. 188, 1691-1703. 
Thucydides, Strassler, R. B., and Crawley, R. (1996). The Landmark Thucydides: A Comprehensive Guide to the Peloponnesian War. New York: Free Press.

Tross, D., and Klinman, D. M. (2008). Effect of $\mathrm{CpG}$ Oligonucleotides on vaccine-induced $\mathrm{B}$ cell memory. $J$. Immunol. 181, 5785-5790.

Tsuiji, M., Yurasov, S., Velinzon, K., Thomas, S., Nussenzweig, M. C., and Wardemann, H. (2006). A checkpoint for autoreactivity in human IgM+ memory B cell development. J. Exp. Med. 203, 393-400.

Tuaillon, E., Tabaa, Y. A., Petitjean, G., Huguet, M. F., Pajeaux, G., Fondere, J. M., Ponseille, B., Ducos, J., Blanc, P., and Vendrell, J. P. (2006). Detection of memory B lymphocytes specific to hepatitis B virus (HBV) surface antigen (HBsAg) from HBsAgvaccinated or HBV-immunized subjects by ELISPOT assay. J. Immunol. Methods 315, 144-152.

Vallé, A., Zuber, C. E., Defrance, T., Djossou, O., Riem, M. D., and Banchereau, J. (1989). Activation of human B lymphocytes through CD40 and interleukin 4. Eur. J. Immunol. 19, 1463-1467.

Van Kooten, C., and Banchereau, J. (2000). CD40-CD40 ligand. J. Leukoc. Biol. 67, 2-17.

Victora, G. D., Schwickert, T. A., Fooksman, D. R., Kamphorst, A. O., Meyer-Hermann, M., Dustin, M. L., and Nussenzweig, M. C. (2010). Germinal center dynamics revealed by multiphoton microscopy with a photoactivatable fluorescent reporter. Cell 143, 592-605.

Wei, C., Anolik, J., Cappione, A., Zheng, B., Pugh-Bernard, A., Brooks, J., Lee, E. H., Milner, E. C., and Sanz, I. (2007). A new population of cells lacking expression of $\mathrm{CD} 27$ represents a notable component of the B cell memory compartment in systemic lupus erythematosus. $J$. Immunol. 178, 6624-6633.

Weigert, M. G., Cesari, I. M., Yonkovich, S. J., and Cohn, M. (1970).
Variability in the lambda light chain sequences of mouse antibody. Nature 228, 1045-1047.

Weiss, G. E., Crompton, P. D., Li, S., Walsh, L. A., Moir, S., Traore, B., Kayentao, K., Ongoiba, A., Doumbo, O. K., and Pierce, S. K. (2009). Atypical memory B cells are greatly expanded in individuals living in a malaria-endemic area. J. Immunol. 183, 2176-2182.

Weller, S., Braun, M. C., Tan, B. K., Rosenwald, A., Cordier, C., Conley, M. E., Plebani, A., Kumararatne, D. S., Bonnet, D., Tournilhac, O., Tchernia, G., Steiniger, B., Staudt, L. M., Casanova, J. L., Reynaud, C. A., and Weill, J. C. (2004). Human blood IgM "memory" $B$ cells are circulating splenic marginal zone B cells harboring a prediversified immunoglobulin repertoire. Blood 104,3647-3654. Weller, S., Faili, A., Garcia, C., Braun, M. C., Le Deist, F. F., De Saint Basile, G. G., Hermine, O., Fischer, A., Reynaud, C. A., and Weill, J. C. (2001). CD40-CD40L independent Ig gene hypermutation suggests a second B cell diversification pathway in humans. Proc. Natl. Acad. Sci. U.S.A. 98, 1166-1170.

Weller, S., Mamani-Matsuda, M., Picard, C., Cordier, C., Lecoeuche, D., Gauthier, F., Weill, J. C., and Reynaud, C. A. (2008). Somatic diversification in the absence of antigen-driven responses is the hallmark of the IgM+ IgD + CD27+ B cell repertoire in infants. J. Exp. Med. 205, 1331-1342.

White, H., and Gray, D. (2000). Analysis of immunoglobulin (Ig) isotype diversity and $\operatorname{IgM} / \mathrm{D}$ memory in the response to phenyl-oxazolone. J. Exp. Med. 191, 2209-2220.

White, M. B., Word, C. J., Humphries, C. G., Blattner, F. R., and Tucker, P. W. (1990). Immunoglobulin D switching can occur through homologous recombination in human B cells. Mol. Cell. Biol. 10, 3690-3699.

Wilson, P. C., Wilson, K., Liu, Y.J., Banchereau, J., Pascual, V., and
Capra, J. D. (2000). Receptor revision of immunoglobulin heavy chain variable region genes in normal human B lymphocytes. J. Exp. Med. 191, 1881-1894.

Wirths, S., and Lanzavecchia, A. (2005). $\mathrm{ABCB} 1$ transporter discriminates human resting naive $B$ cells from cycling transitional and memory B cells. Eur. J. Immunol. 35, 3433-3441.

Wrammert, J., Koutsonanos, D., Li, G.M., Edupuganti, S., Sui, J., Morrissey, M., Mccausland, M., Skountzou, I. Hornig, M., Lipkin, W. I., Mehta, A., Razavi, B., Del Rio, C., Zheng, N.-Y., Lee, J.-H., Huang, M., Ali, Z., Kaur, K., Andrews, S., Amara, R. R., Wang, Y., Das, S. R., O’Donnell, C. D., Yewdell, J. W., Subbarao, K., Marasco, W. A., Mulligan, M. J., Compans, R., Ahmed, R., and Wilson, P. C. (2011). Broadly cross-reactive antibodies dominate the human $\mathrm{B}$ cell response against 2009 pandemic H1N1 influenza virus infection. $J$. Exp. Med. 208, 181-193.

Wrammert, J., Smith, K., Miller, J., Langley, W. A., Kokko, K., Larsen, C., Zheng, N.-Y., Mays, I., Garman, L., Helms, C., James, J., Air, G. M., Capra, J. D., Ahmed, R., and Wilson, P. C. (2008a). Rapid cloning of high-affinity human monoclonal antibodies against influenza virus. Nature 453, 667-671.

Wrammert, J., Smith, K., Miller, J., Langley, W. A., Kokko, K., Larsen, C., Zheng, N. Y., Mays, I., Garman, L., Helms, C., James, J., Air, G. M., Capra, J. D., Ahmed, R., and Wilson, P. C. (2008b). Rapid cloning of high-affinity human monoclonal antibodies against influenza virus. Nature 453, 667-671.

Yasui, H., Akahori, Y., Hirano, M., Yamada, K., and Kurosawa, Y. (1989). Class switch from $\mu$ to $\delta$ is mediated by homologous recombination between $\sigma \mu$ and $\sigma \mu$ sequences in human immunoglobulin gene loci. Eur. J. Immunol. 19, 1399-1403.

Yu, X., Tsibane, T., Mcgraw, P. A., House, F. S., Keefer, C. J., Hicar,
M. D., Tumpey, T. M., Pappas, C., Perrone, L. A., Martinez, O., Stevens, J., Wilson, I. A., Aguilar, P. V., Altschuler, E. L., and Basler, C. F., Crowe, J. E. Jr. (2008). Neutralizing antibodies derived from the B cells of 1918 influenza pandemic survivors. Nature 455, 532-536.

Zandvoort, A., and Timens, W. (2002). The dual function of the splenic marginal zone: essential for initiation of anti-TI-2 responses but also vital in the general first-line defense against blood-borne antigens. Clin. Exp. Immunol. 130, 4-11.

Zheng, N.-Y., Wilson, K., Wang, X., Boston, A., Kolar, G., Jackson, S. M., Liu, Y.-J., Pascual, V., Capra, J. D. and Wilson, P. C. (2004). Human immunoglobulin selection associated with class switch and possible tolerogenic origins for C $\delta$ classswitched B cells. J. Clin. Invest. 113, 1188-1201.

Conflict of Interest Statement: The authors declare that the research was conducted in the absence of any commercial or financial relationships that could be construed as a potential conflict of interest.

Received: 14 October 2011; accepted: 29 November 2011; published online: 15 December 2011.

Citation: Pauli NT, Henry Dunand CJ and Wilson PC (2011) Exploiting human memory $B$ cell heterogeneity for improved vaccine efficacy. Front. Immun. 2:77. doi: 10.3389/fimmu.2011.00077

This article was submitted to Frontiers in B Cell Biology, a specialty of Frontiers in Immunology.

Copyright (C) 2011 Pauli, Henry Dunand and Wilson. This is an open-access article distributed under the terms of the Creative Commons Attribution Non Commercial License, which permits noncommercial use, distribution, and reproduction in other forums, provided the original authors and source are credited. 